\title{
Art and cartography as a critique of borders
}

\author{
Daniel Melo Ribeiro $^{\mathrm{a}}$ \\ ${ }^{a}$ Communication and Semiotics, Pontifical Catholic University of São Paulo, Brazil.danielmeloribeiro@gmail.com
}

\begin{abstract}
This study focuses on the relationship between art and cartography. The main objective is to analyze how contemporary art uses maps to criticize borders. Inspired by the arguments raised by the Critical Cartography against the false neutrality of maps, we emphasize the potential of artworks to communicate different insights about how we experience and live the contemporary space. In that sense, art plays an important role not only to discuss the articulation of power and knowledge in cartography, but also to propose other categories of thought. Considering that borders are one of the most relevant visual elements on a map, we propose the following question: how the intersection between art and cartography can improve the critical thinking about borders? By questioning borders, art underlines that physical world is characterized by liminal spaces, not by absolute or strict separations. We briefly analyzed some examples of artworks that deal with political issues regarding this topic. Our findings suggest that art could reveal the impact of imposing borders in a space, whose arbitrary delimitation reflects power relations.
\end{abstract}

Keywords: Cartography, Borders, Liminal Spaces, Threshold, Art

\section{Introduction}

"The border was all in my mind" (Popescu 2012, IX).

In a certain regard, borders are contradictory. They are one of the most visible elements on a map: through these lines, readers can easily identify countries and states. In that sense, borders are essential to put some order in a space. On the other hand, the real space is naturally borderless. It is common to physically cross some borders with-out noticing any particular explicit division. However, we know that borders are real: if it is indicated on a map, the border must be there.

When it comes to globalization, the contradiction of borders appears more clearly. Mobility and telecommunication supposedly could trespass these separations, shortening distances and connecting places. Nevertheless, it seems that contemporary society does not wish to remove borders. Instead, even more separations between places are being erected: walls, surveillance apparatus, passports, immigration rules. And all these strategies are mostly unequally applied, according to political and economic interests.

Thus, borders are conventions. They are social constructions that reflect power relations. Borders do not represent a natural division of spaces, but a political rule that artificially imposes separation in a space that was originally more fluid. Therefore, borders are able to change our own perception of the space, creating places instead of just representing them.

From that perspective, borders and maps communicate and attest these conventions. Historically, maps are recognized as an effective communication device that consolidate (or contest) power relations. For example, supported by scientific cartography standards, maps became instruments of national states. However, the power of maps can be challenged. In the hands of contemporary artists, maps are being completely distorted, an attitude that stimulates a critical thinking about the role of the cartography. Considering this artistic approach against carto-graphic conventions, it is more evident that maps are not neutral: there are always implicit intentions behind maps. Besides that, the distortion of maps for aesthetic purposes could reveal other perspectives of the space, particularly the way we perceive borders. Therefore, this idea leads to the main question of this study: how the intersection be-tween art and cartography can improve the critical thinking about borders?

In order to understand how contemporary artworks could stimulate a critical approach about borders, it is essential to remember some basic points about the Critical Cartography. It is also relevant to mention how the Critical Cartography sees art as an encouraging field to propose alternative points of view about the space. By questioning borders, we suggest that art shows that physical world is characterized by liminal spaces, not by absolute or strict separations.

With regard to liminal spaces, there will be recovered some thoughts about the notion of thresholds, a concept that was developed by Walter Benjamin. Anticipating some characteristics of the postmodernism, Benjamin alerted, in the first decades of the 20th century, that our society are becoming poor in threshold experiences. This means that areas of transition are being overcome by rigorous separations. However, liminal spaces could reveal interesting features about our relation with spaces. They represent a kind of resistance against the authority of borders.

Therefore, the main objective of this study is to analyze how contemporary art uses maps to criticize borders. For that, there will be investigated some artworks. Recovering Critical Cartography investigations to support discussions about borders in arts, this study also raise questions about the arbitrary delimitation of spaces that 
are other-wise composed by diversity, power relations and conflict.

\section{The Critical Cartography: alternative ways of mapping spaces}

In the context of the debates raised both by the postmodernity (Jameson 1996; Harvey 2006) and the spatial turn (Soja 1993), a group of geographers began to question the apparent neutrality of the scientific cartography. These authors wanted to rethink the mapping activity, both from a professional and an academic point of view. This movement is known as the Critical Cartography and the main researchers associated with this trend are J. B. Harley, Denis Wood, Jeremy Crampton, John Pickles, among others.

According to Harley (2001), the scientific cartography assumes that spatial reality could be represented in mathematical terms. Implicit in this assumption, there is the notion of a cartographical truth, which could only be achieved by empirical observation and measurement. Under these circumstances, the map is considered an instrument that claims a rigorous correspondence with the territory. The cartographer becomes a technician who strives to develop an increasingly "neutral" interface based on strict conventions. From this perspective, the map seeks to communicate geographical aspects accurately, such a road or a border for example. Therefore, the scientific cartography emphasizes functional aspects of the map, its reliability and its effectiveness.

However, the main argument of the critical cartographers is that maps are not neutral. In fact, maps are far from being a transparent window to the world. Harley advises that every map must be interpreted as a political discourse that imposes a certain construction of the reality, expressing relations of power and cultural values. Like any other document, maps are full of intentions and propositions. Accordingly, they should not be understood as a plain re-flection of the territory, but rather as a kind of socially constructed image that refracts a certain point of view. Therefore, a critical approach of the cartography recognizes that a map - a visual communication device created by men to give meaning to the world - will never be able to neutrally represent reality.

In that sense, maps are intentionally rhetorical. This discursive characteristic of maps also make them a powerful vehicle for transferring authority over territory (Wood 2010). An example of how power relations are expressed in maps can be found in the way cartography have been historically exploited by state authorities as instruments of nationalism. Particularly in the context of the colonialism, maps were broadly used to legitimate imperial conquests, as well as to claim borders and possession over disputed lands (Harley 2001; Pickles 2004). Thus, revealing such power relations behind maps constitutes an essential step to criticize cartography.

But, what does the notion of criticism exactly mean in the Critical Cartography? According to Crampton (2010), the original sense of the concept refers to philosophy.
Supported by Foucault, Kant, and other philosophers from the Frankfurt School, Crampton emphasizes that criticism is not a deliberate attempt to find a fault in an argument and neither a disapproving judgment. Instead, the criticism is an examination of premises and foundations of a certain field of knowledge. It is a philosophical approach that, from a historical perspective, investigates the relation-ship between power and knowledge. "In other words, critique is a political practice of questioning and resisting what we know in order to open up ways of knowing" (Crampton 2010, 15). Considering this philosophical ground, it becomes clear how the Critical Cartography reviews the nature of maps. Mapping is not a simple reflection of the spatial reality, but a way of producing knowledge. Under this perspective, some questions regarding maps could be proposed, such as: what criteria define a map as right or wrong? Who classifies maps as good or bad? What authority has been assigned to these people to judge maps? Are there other map-ping strategies? What would these alternative mapping strategies review? This critical attitude towards maps helps to disclose the relations of power embedded in the scientific cartography. It also encourages the creation of alternative ways of mapping space, embracing non-western and non-traditional mapping practices.

Among these different mapping practices, this study focus on the alternative perspectives provided by arts. We support the idea that contemporary art plays an important role not only to discuss the relationship between power and knowledge in cartography, but also to propose other categories of thought.

\section{Art and Cartography: a critical approach towards mapping}

From the early decades of the 20th century, the contemporary art turned into an appealing field to criticize standards and conventions in society. Artistic movements such as Surrealism, Dadaism and Cubism assumed a political attitude, based on a radical disruption with the traditional artistic values, an approach that definitely changed the meaning of art in the following years.

These artistic movements deeply influenced artists to create new practices of map art. According to Denis Wood (2010), the creative power of maps was inspired by techniques of collages and montages promoted both by Dada-ism and Surrealism. Since then, artists began to extensively use maps and cartographic elements. Employing several techniques like painting, sculpture, engraving, photography, collage, drawing, performance and installation, these artists play with maps in a prolific way: cutting it, folding it, burning it, wearing it or even tattooing it (Harmon \& Clemans 2009).

One of the most significant impacts of map art is the explicit message against the false neutrality of the formal cartography. Accentuating aesthetic purposes, artists clearly distort cartographic conventions. Paul Éluard's Le monde au temps des Surréalistes and Joaquín Torres 
García's América Invertida are examples of artworks that question cartographic standards. Playing with scales and inverting traditional orientations, these maps encourage a political reading about society.

Therefore, this study emphasizes the potential of artworks to communicate different insights about how we experience and live the contemporary society. Since art does not fit into the constraints of the formal disciplines such as cartography, it could suggest other mapping practices, expanding our understanding about space. From this perspective, we propose that art can be a provocative strategy to criticize cartography. Particularly, we will focus on the following question: how the intersection between art and cartography can improve the critical thinking about borders? But, before that, it is important to mention what border is, as well as its relationship with maps.

\section{Border: an arbitrary line in a map}

Among several map properties, there is a crucial visual element: the representation of borders, understood here as an arbitrary delimitation of a certain space. According to Popescu (2012), borders are usually conceived as lines that set up limits on a space, carrying a sense of division or separation. Borders are essential to attribute a practical meaning to spaces. "Borders are discontinuities in space that render space meaningful by compartmentalizing it into distinctive units" (Popescu 2012, 9).

However, such strict division is not natural: borders are rules that artificially establish a way of controlling movement in space. In general, the creation of borders are based on political decisions, often involving tensions and power dispute. It is a procedure that inscribes a clear difference in space, a traditional instrument of ordering society. In that sense, borders are historically defined to "mediate between the familiar of here and the unfamiliar of there" (Popescu 2012, 7). A border regulates what should come and go, as well as who is part of my group, and who is either a stranger or an outsider.

Borders are conventions that must be clearly communicated to avoid unintended transgression. Therefore, borders are also discourses: they must be constantly reinforced, in order to keep their message strong. Although borders could be visually identified using different strategies - such a wall, a fence, a sign, a checkpoint, a national flag, a police booth, a bridge - the way a border is clearer expressed is through a line in a map. When it comes to national affairs, maps are certainly one of the most powerful ways of imposing borders over a territory. As we mentioned, a map does not simply reproduces the world: it builds and naturalizes certain cultural achievements. It is through maps that national borders are born (Carou, 2001).

Essentially, borders are also lines. According to Pickles $(2004,3)$, "the drawing of lines is a fundamentally geographical and spatial act". Lines are the basic principle behind cartography: drawing and interpreting them constitutes a fundamental skill that creates and domesticates the world, originating more complex categories of thought, such as classifications, hierarchies and taxonomies. In that sense, lines in a map also contribute to create identities and a sense of belonging. "We have lived within the lines we have traced and been made the subjects we have be-come." (Pickles 2004, 3).

However, people's perception of the real space could not exactly correspond to this rigid definition. A line in a map creates a dichotomic separation that could be totally distinct of a physical experience of crossing a border. Although some borders could correspond to more obvious physical delimitation such rivers or mountains, it does not exclude the existence of liminal spaces (Carou 2001), or spaces of transition.

\section{Liminal spaces, threshold experiences}

Some concepts could be used to define spaces of transition that lies between borders. For example, the notion of borderlands "reveal a more gradual transition in space from one state territory to another, rather than a sharp and swift encounter as border lines would have it" (Popescu 2012, 78). According to Popescu, borderlands does not correspond to abstract spaces: in contrast with borders, borderlands are places where people could live, blurring the artificial sense of separation. As examples of borderlands, Popescu mentions some parts of the USMexico frontier and Pakistan's Northwest Territories.

The concept of frontier also assumes a particular meaning. It suggests contact, a sort of physical touch that could allow some communication between two entities. From a geopolitical perspective, frontiers "incorporated a significant mixture of populations and cultures, were loosely controlled by their political centers, and provided a gradual transition from one state to another" (Popescu 2012, 17). According to Carou (2001), the concept of frontier could also be interpreted as a synonym of borderlands: an area in which some communities interpenetrate mutually, share experiences and have frequent contacts.

Apart from this geopolitical perspective, the topic of liminal spaces also instigated a philosophical criticism. For example, Walter Benjamin - a German philosopher contrasted the concepts of border and threshold. As we mentioned, the notion of border claims a clear delimitation of space, frequently imposed by arbitrary rules which cannot be illegally trespassed. On the other hand, the notion of threshold not only indicates the separation of two ambiences, but also includes aspects of transition, gradual change, movement. Therefore, this is a concept that connects space and time, allowing a transition between two points, experiencing limits, testing forces, leaving the comfort zone, risking new approaches. This interpretation of threshold can be used as a metaphor to describe Walter Benjamin's critical thought: a philosopher who dared to support the experience of uncertainty and deviation (Barrento 2013, Gagnebin 2014). Benjamin suggests that "we have grown very poor in threshold experiences" (Benjamin \& Tiedemann 1999, 494). In this fragment, Benjamin says that "transitions are becoming even more unrecognizable and impossible to 
experience in modern life" (ibid., 494). Focusing on small and despised features of the society that lies in thresholds, Benjamin indicates his own research method: the knowledge that appears in-between, contrasting here and there. Ac-cording to Jennings $(1987,12)$, one of the main aspects of the Benjamin's theory of criticism is the conviction that truth "is present to the modern world in hidden and fragmentary form". And this truth could be reached through threshold experiences in the liminal spaces.

Nevertheless, how the discussions about liminal spaces could be useful to criticize borders? We suggest that one of the roles of visual arts is conceiving critical experiences about the space in contemporary society. By confronting borders, we believe that the art is able to show that real spaces are characterized by thresholds, not by absolute or strict separations.

\section{Criticizing borders through map art}

The figure 1 shows a photograph of an installation art called Area Restringida (Restricted Area), created by Mateo Maté, an artist from Madrid. In this artwork, there is a continuous black ribbon, supported by white poles, which draw a closed shape. In a corner of the room, outside the shape, there is a person sitting on a chair, watching three monitors. A surveillance camera can also be seen on the wall.

Like a map, this shape represents the territorial limits of the whole American continent. The black ribbons supported by the white poles are actually queue organizers, or stanchions. These stanchions are typically used to control the flow of people in places such as airports, banks, museums, amusement parks, and public offices. However, the shape does not offer any entrance to the visitor, so it is impossible to cross these borders. On purpose, the artist erected these borders and blocked the access, forcing visitors to circulate outside. Besides preventing people to cross the borders of this territory, the artist included a surveillance system, with cameras and security agents: one of them carefully watches monitors, while the other stands right in front of the door.

In this artwork, Mateo Maté incites discussions about surveillance and migration, crucial issues in contemporary society. Using these stanchions as a metaphor of the contemporary borders, the artist causes an immediate feeling of prohibition and arbitrariness. The title of the work itself reinforces the message of an enclosed space, whose ac-cess is not authorized to any strange visitor. In addition, the disturbing presence of the surveillance apparatus stresses the punishing presence of the law. Thus, the image does not appear as a simple map of the continent. It connects our previous cartographic knowledge with several situations in which we were prevented from moving through such artificial divisions. Therefore, it is an artwork that induces a critical analysis about borders.

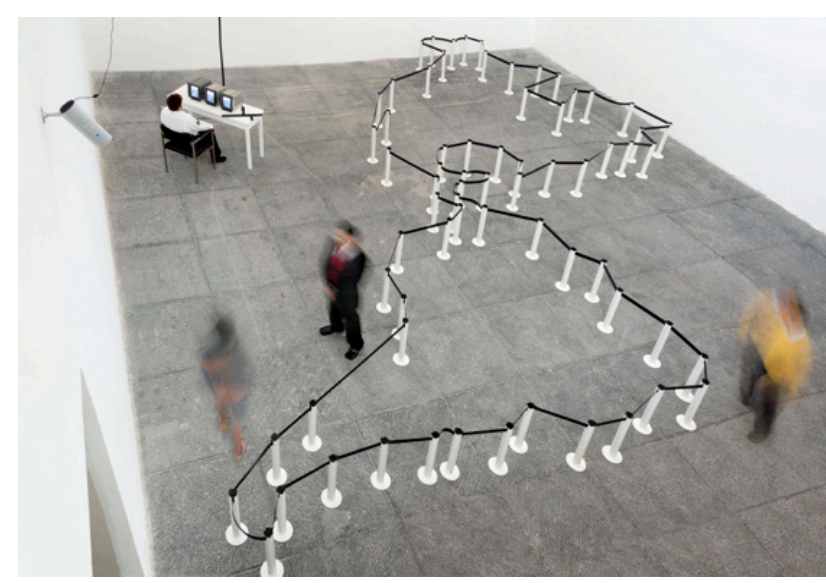

Fig. 1. Área Restringida, Mateo Maté. Sala de Arte Siqueiros, Mexico D.F. 2011 (Source: artist's website. Available in: http://www.mateomate.com/area-restringida/. Accessed 22 Feb 2017)

The second artwork in the figure 2 is called Upotia, created by Nicolas Desplats. These are six closed buckets, typical paint cans used on walls and other surfaces. Each bucket contains a label that covers the whole side surface. These labels show the title of the artwork in large characters, as well as other explanatory texts. The lid of each bucket shows map images, with common cartographic elements such as meridian and parallel lines, roads, city names, and borders. These buckets appear to be tightly closed, not showing any sign that they might have been opened. Each bucket also contains names of islands that are situated between the cities of Marseille (where the art-ist lives) and Toulon, where the exhibition took place (Monsaingeon 2013).

The title Upotia comes from a combination of the words pot and utopia. In that sense, the artist refers to the famous concept of utopia, which means a non-place (utopos), a place that either does not exist or is inaccessible. Utopia would be a perfect society, a model of justice, equality and happiness for its inhabitants. Nowadays, the word utopia has come to mean a kind of impossible dream, an illusion that does not find support in reality (Claeys 2013).

In this artwork, irony is evident. Upotia represents the canned dream of a perfect cartography. It would allow the cartographer to fulfill his desire to draw the ideal border and to delimit space according to his will. Inside each buck-et, we would find the promise of a new place, covering the imperfections of our reality and renewing our hopes for a better future. Another insight that could emerge from this artwork is that maps are seen as a kind of commercial product sold on shelves, a ready-made solution to reveal truths about our world. Thus, the impossibility of achieving utopia is revealed by the promise of a fake product that ensures miraculous effects. 


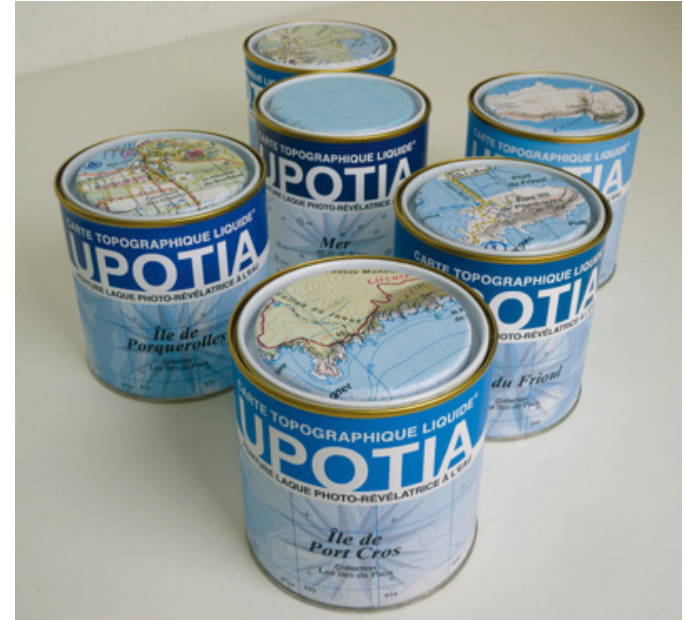

Fig. 2. Upotia: les îles de PACA, Nicolas Desplats. Mappamundi exposition, Hôtel des arts, Toulon, France, 2013. (Source: http:/documentsdartistes.org/artistes/desplats/repro43.html. Accessed 22 Feb 2017)

The third example comes from Francis Alÿs, a Belgian artist that proposed performances in two of the most controversial borders worldwide: the US-Mexico border and the Green Line in Israel. In 1997, Alÿs was invited to join the InSite exhibition held in the San Diego-Tijuana border region. For this exhibition, Alÿs prepared a performance called The Loop: his purpose was to travel from Tijuana to San Diego without crossing the USMexico border. In order to accomplish this long and expensive journey, Alÿs did a circumnavigation around the Pacific Ocean (figure 3). His itinerary comprised the following cities: Tijuana, Mexico City, Panama City, Santiago, Auckland, Sydney, Singapore, Bangkok, Rangoon, Hong Kong, Shanghai, Seoul, Anchorage, Vancouver, Los Angeles, and finally San Diego. With this performance - an extravagant and wasteful trip - Alÿs criticizes the economic and political obstacles that Mexicans are facing. Therefore, crossing that border is privilege that is allowed only for few people.

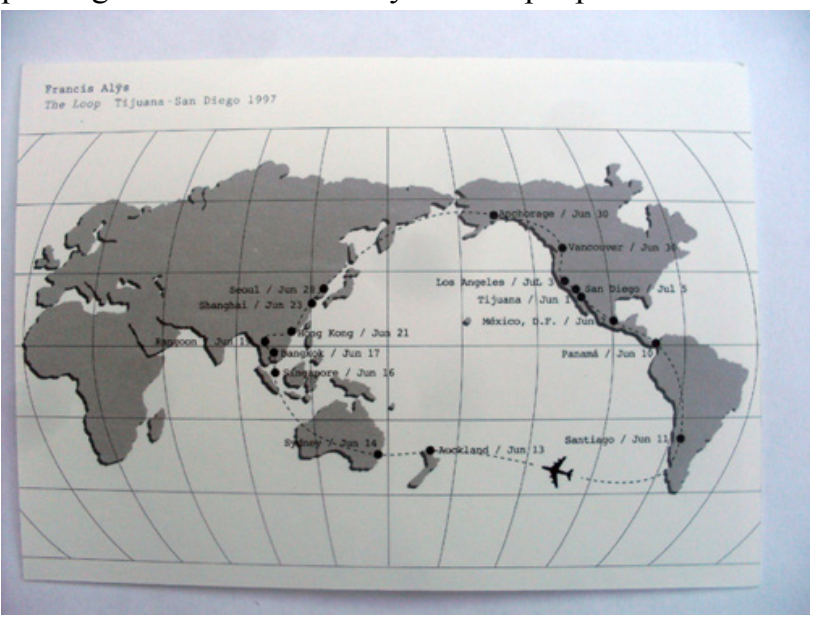

Fig. 3. Francis Alÿs itinerary in The Loop, 1997. (Source: http://pietmondriaan.com/tag/francis-alys/. Accessed 22 Feb 2017)

The other artwork is called The Green Line and it refers to a demarcation created in 1949 due to an armistice agreement between Israel and its neighbors. The line was drawn by a military commander, using a green pencil on a map (Harmon \& Clemans 2009), and it separated some disputed Palestinian territories in the West Bank. This demarcation had an extensive impact in local population. From both sides, their lives were affected by administrative, cultural, religious and security issues. Although that demarcation line was officially removed some decades later, its effects are still present. Since then, the line became a clear example of how an artificial decision on a map could impose power relations over a territory.

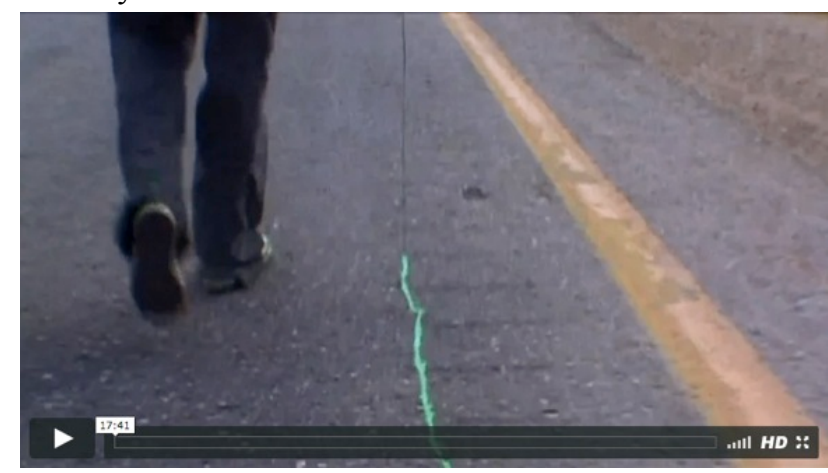

Fig. 4. The Green Line. Francis Alÿs. Jerusalem 2004. (Source: artist's website. Available in: http://francisalys.com/the-greenline/. Accessed 22 Feb 2017)

In 2004, Alÿs proposed the following performance: he walked the region affected by the Green Line, spilling a green paint on the ground behind him ${ }^{1}$. A video was recorded during his performance along a distance of 24 $\mathrm{km}$. In a general sense, his walking performance shows the contrast between conceiving a border on a map and physically perceiving it in a real place. Besides that, the political aspect of borders is emphasized in this artwork: tracing a line on a piece of paper could be a gesture that causes a huge impact in people's life. It is not coincidence that similar decisions based on arbitrary lines also happened in other key historical situations. We could mention the Treaty of Tordesillas - a political agreement that divided the world between Spain and Portugal at the end of the 15 th century. Or even the trace of the Berlin wall, another arbitrary division with a deep political and social consequences. All these examples demonstrate how strong borders are. Nevertheless, Alÿs' work also shows that it is possible to con-test these decisions, and one of the ways to resist is through art. In his own words, "sometimes doing something poetic can become political. And sometimes doing something political can become poetic" (Alÿs 2004).

\section{Conclusions}

The intersection between cartography and art reveals a fruitful ambient for expanding the limits of established mapping techniques. In order to inspire aesthetic experiences, artists plays with cartographic conventions, disclosing hidden features of the space. This approach

\footnotetext{
${ }^{1}$ A similar proposal was created by the artist Alban Biaussat in 2005, with an artwork called The Gren(er) Side of the Line (Harmon \& Clemans, 2009).
} 
purposely disturbs our beliefs, suggesting alternatives that challenge traditional notions of space. Supported by that characteristic, art becomes a field that embraces and welcomes political and critical messages about rules in society.

Our findings also suggest that art could show the impact of imposing borders in a space, whose arbitrary delimitation reflects power relations. When these relations are exposed, people are more likely to think critically about the impact of borders in their lives. It is also worth mentioning that, although the representation of borders plays a key role in maps, its arbitrariness may hide an essential feature: the pertinence and the value of the liminal spaces.

\section{Acknowledgements}

We are grateful to the professor Sébastien Caquard and the Geomedia Lab researchers at the Concordia University in Montréal/CA. This work is funded under grants from the CNPq Brazil and Global Affairs Canada ELAP Pro-gram.

\section{References}

Alÿs, F. (2004). The Green Line: Video documentary. Artist's website. Available in: http://francisalys.com/the-green-line/

Barrento, J. (2013). Limiares em Walter Benjamin. Florianópolis: Edufsc.

Benjamin, W., \& Tiedemann, R. (1999). The arcades project. Harvard University Press.

Cairo Carou, H. (2001). Territorialidad y fronteras del estado-nación: Las condiciones de la política en un mundo fragmentado. Polí-tica y sociedad, (36), 29-38.

Claeys, G. (2013). Utopia: a história de uma ideia. São Paulo: Edições SESC SP.

Crampton, J. W. (2011). Mapping: A critical introduction to cartography and GIS (Vol. 11). Chichester, UK: John Wiley \& Sons.

Gagnebin, J. M. (2014). Limiar, aura e rememoração: ensaios sobre Walter Benjamin. São Paulo: Ed. 34.

Harmon, K., \& Clemans, G. (2009). The Map As Art: Contemporary Artists Explore Cartography. Princeton Architectural Press.

Harley, J. B. (2001). The new nature of maps: essays in the History of Cartography. Baltimore: The Johns Hopkins University Press.

Harvey, D. (2006). Condição pós-moderna: uma pesquisa sobre as origens da mudança cultural. São Paulo: Edições Loyola.

Jameson, F. (1996). Pós-modernismo: a lógica cultural do capitalismo tardio. São Paulo: Ática.

Jennings, M. W. (1987). Dialectical images: Walter Benjamin's theory of literary criticism. Cornell University Press.

Monsaingeon, G. (2013). Mappamundi: art et cartographie. Parenthèses.
Pickles, J. (2004). A history of spaces: Cartographic reason, mapping, and the geo-coded world. New York: Routledge.

Popescu, G. (2012). Bordering and ordering the twentyfirst century: Understanding borders Plymouth, UK: Rowman \& Littlefield.

Soja, E. (1993). Geografias Pós-modernas: a reafirmação do espaço na teoria social crítica. Rio de Janeiro: Zahar.

Wood, D. (2010). Rethinking the power of maps. New York: Guilford Press. 